UDC 615.21.3:34+616-039.42

\title{
THE PRIMARY ASSESSMENT OF PRESCRIBING DRUGS FOR THE ELDERLY PEOPLE CONDUCTED BY PHARMACISTS
}

\author{
T. Schiopu, M. Brumărel, S. Adauji \\ Nicolae Testemitanu State University of Medicine and Pharmacy of the Republic of Moldova. \\ E-mail: schiopu.tatiana@usmf.md, stela.adauji@usmf.md
}

In conditions of the fast growing number of older population the problem of pharmaceutical care for this category of people is more often tackled by international bodies. The most important problem in this area is that the impact of drugs on the elderly people has been insufficiently studied and is not properly interpreted. Aging brings increase in the use of drugs together with the growth in frequency of side effects to a medication, drug-drug interactions, interactions between drugs and the disease and other problems related to the drug use. There is no statistical evidence in the Republic of Moldova related to the health state of people above 65, as well as there is no data about their access to healthcare and pharmacy services. In this context, the studies in geriatric pharmacy are of great current interest and practically significant. The study material was prescriptions collected from public pharmacies within 5 months. In the study 1339 prescriptions were analyzed. The data collected were age, gender, dates of drug prescribing and its dispensing, the amount of the drug dispensed to one patient, the active substance and its dose. Based on the data analyzed the current issues associated with drug therapy, dosing, drug-drug interactions, and side effects have been determined; the practical recommendations for pharmacists related to the treatment advice given to this group of patients, including the volume and quality of the information about the medication dispensed, have been proposed.

Key words: pharmacists; pharmaceutical care; elderly people; pharmaceutical therapy; expected therapeutical results.

Statement of the problem. There is no statistical evidence in the Republic of Moldova related to the health state of people above 65 , as well as there is no data about their access to healthcare and pharmacy services. Aging brings increase in the use of drugs together with the growth in frequency of side effects to a medication, drug-drug interactions, interactions between drugs and the disease and other problems related to the drug use. The impact of drugs on the elderly people has been insufficiently studied in our country. The assessment of medications used by the elderly people is

T. A. Schiopu - a teaching assistant of the Social Pharmacy Department named after V. I. Prokopishin of the Nicolae Testemitanu State University of Medicine and Pharmacy of the Republic of Moldova (Chisinau) recommended in order to identify and solve the problems related to their use. The objective of any assessment conducted on the medication does not mean reduction of the number of drugs used, but achievement of the expected results and decrease of number of problems related to the drug use.

Analysis of recent research and publications. At the global level, in more developed countries, as well as in developing ones, the positive impact of pharmacist's interventions on communication with the elderly people is well supported by numerous studies. Based on the monitoring services and data of drugs used in ambulatory treatment the key skills and responsibilities for pharmacists as specialists in healthcare have been determined. The added 
value brought by pharmacists as part of services provided towards the elderly people is represented by sharing the information, ideas and advice and is aimed to increase the effect of the pharmaceutical product, leading to its correct and efficient use, providing the optimal results for a patient $[1,6,9]$.

International practices have shown that monitoring services of medical therapies (for hypertension, dyslipidemia, diabetes, heart failure, chronic obstructive pulmonary disease and insomnia) offered by pharmacists have a positive impact on the treatment compliance, reducing medication errors and side effects, as well as interactions between drugs, etc. [6, 8].

The fact that the irrational use of a drug and the treatments not being followed correctly by the elderly people does not bring expected, but severe consequences on the health is obvious.

Thus, technical and educational approach to the therapy of the elderly patients tends to increase the level of their knowledge about the disease and its treatment. The study conducted has an observational approach, but the conclusions have revealed the need of an interventional research to evaluate the degree of acceptance and implementation of pharmacists' recommendations performed to optimize the therapy of the elderly people.

It is also very important to improve the level of knowledge of the elderly people about the drug they use. In this way, if a patient knows what drugs to use, why and what the benefits of its use are, the incorrect use of a medication is reduced $[4,6,7,9]$.

Objective statement of the article. The primary assessment of drugs used by the elderly people and determination of potential problems related to drug therapy.

In order to achieve the objective proposed the following targets were set:

- to gather prescriptions made to the elderly people and select a medication;

- to analyze the drug list prescribed to the elderly people based on the explicit analysis of the criteria validated by the pharmaceutical systems such as Beers, START/STOP;

- to determine the potential problems related to the drug administration;

- to develop recommendations to pharmacists concerning the pieces of advice to be given to the elderly people.
Material and methods. A transversal descriptive study describing the features of the older people, common diseases and offering a simple description of their drug related problems was proposed for this research. The study material was prescriptions collected from public pharmacies within 5 months. In the study 1339 prescriptions were analyzed. The data collected were age, gender, dates of drug prescribing and its dispensing, the amount of the drug dispensed to one patient, the active substance and its dose.

Results. In order to analyze the drug therapy (administration of drugs) for the elderly people the reports about the medications partially/totally refunded and dispensed within 5 months in a public pharmacy were gathered. In the study 1339 prescriptions were analyzed. The total number of patients was 704 . Out of total, 305 (43.3\%) patients were people over 65 years of age, there were 220 women and 85 men; the rest were people under 65 pregnant women, adults and children. Out of total prescriptions, there were only 441 prescriptions for the elderly people.

The analysis of prescriptions revealed that the most frequent categories of the drugs requested were the following categories: antihypertensive drugs - $44 \%$ (angiotensin-converting enzyme inhibitors, calcium channel blockers, beta-blockers, vasodilators), antidiabetic drugs - 19\% (oral and for injection), diuretics $16 \%$, antithrombotic anticoagulants $-6 \%$, ulcer drugs - $5 \%$, other drugs - $10 \%$ (thyroid hormones, psychotropic drugs, antidepressants, antiepileptic, asthma medication, glaucoma and miotic drugs).

As result of the analysis of the number of drugs and their scope of use it has been found that almost all people suffer from the same disease - hypertension, and only those who are much more older suffer from 2 diseases at the same time (hypertension combined with diabetes type II in $70 \%$ of the cases, and less frequent combined with thyroid gland disease, ulcer disease and thromboembolic disease).

The number of drugs used is very important in assessing medications used by the elderly people. On average an elderly person uses 1-5 drugs simultaneously, the total number being related to the disease. Examples of drugs that are most frequently prescribed are: 
acetylsalicylic acid, 75-100 mg; indapamide, $1.5 \mathrm{mg}$; ramipril, 5-10 mg; amlodipine, 5-10 mg; metformin, $1000 \mathrm{mg}$; gliclazide, $60 \mathrm{mg}$; lisinopril, $10 \mathrm{mg}$; isosorbide dinitrate, $20-40 \mathrm{mg}$; bisoprolol, $5 \mathrm{mg}$; torasemide, $5 \mathrm{mg}$; metoprolol, 50-100 mg; human insulin, $100 \mathrm{IU} / \mathrm{ml}$; losartan, $50 \mathrm{mg}$. For these drugs such items as side effects, contraindications and precautions, interactions with other drugs were analyzed.

The criteria of such groups as Beers, START and STOP validated in other pharmaceutical systems were also analyzed. These groups offer information related to drugs that may be dangerous for using in geriatric therapy, indicators of prescription of drugs for common and specific diseases to the elderly people, potential interactions between drugs, and doubling of prescriptions for the similar groups of drugs $[2,3,5]$.

These criteria serve to assess the risks associated with drug administration by the elderly people. It has been found that $60 \%$ of drugs prescribed should be used with precaution according to Beers criteria, $10 \%$ should be avoided according to STOP criteria, and there are no studies of 7 drugs, which would prove the efficiency of their use by the elderly people.

Another fact that influences on the correct use of a medication is the match of the prescription date with dispensing of drugs, and it impacts on the treatment compliance of the patients. This fact is important for continuity of the treatment if the patient does not stop the use during the treatment because of the lack of the quantity required. It has been found that the majority of the elderly people (52.5\%) adheres to the treatment by getting the drugs during the first 10 days after their prescription, fewer patients (33.3\%) follow exactly the treatment by having their drugs at the same day, and the least number buy drugs during a period longer than 10 days, even after a month or two, depending on the type of drugs (14.2\%).

\section{Conclusions}

Based on the results of the study the current issues associated with drug therapy, dosing, drug-drug interactions, and side effects have been determined; the practical recommendations for pharmacists related to the treatment advice given to this group of patients, including the volume and quality of the information about the medication dispensed, have been proposed.

The following rules for pharmacists concerning the appropriate use of drugs for hypertension and diabetes should be recommended:

- To check if the drug prescribed is appropriate to the needs of the patient, it is effective and safe; to monitor the treatment: dose, use - how and why it is recommended (before, during or after a meal), and the expected results, dosage forms, incompatibilities of the drugs.

- To take into consideration drug interactions, side effects, treatment compliance, and drugdisease interaction.

- To document the drug problems detected, any information on decisions taken about the drug, information offered to the patient and specialists in the field.

- To check the list of drugs for eliminating drugs that are repeated or those that are not adjusted (incorrect dose), to review medications regularly (they should be reviewed every $6-12$ months).

- To take into consideration that the new symptoms can be caused by the use of drugs.

- To evaluate the non-pharmacological treatment - physical therapy, relaxing techniques and behavioral therapy for all detected cases of the inappropriate use of drugs by the elderly; thereby it is highly recommended to minimize the number of tablets, the inconvenience and frequency of taking the drug.

- To collaborate with other pharmacists, physicians with the aim of informing and correcting errors in prescribing and the use of drugs by the elderly people, as well as developing peer relationships. Pharmacists will announce mandatory, periodic problems identified and will contribute to making the right decisions, thus diminishing the number of complications after the inappropriate drug use.

- To use the available pharmaceutical informal resources for counseling, written information, pill packaging and other warning advices, etc.

Prospects for further research. There is the need for developing practical guides for verification and evaluation of the drugs prescribed based on the criteria validated in other 
countries, but adjusted to the real and current needs of patients, as well as to the range of drugs at the pharmaceutical market in the Republic of Moldova and to the possibilities of intervention of pharmacists in solving of drug related problems under conditions offered by the existing public pharmacies.

\section{REFERENCES}

1. Nobili A. Multiple diseases and polypharmacy in the elderly: challenges for the internist of the third millennium/ A. Nobili, S. Garattini, P. Mannuccio Mannucci // Journal of Comorbidity. - 2011. - Vol. 1. P. 28-44.

2. American Geriatrics Society 2012 Beers Criteria Update Expert Panel. American Geriatrics Society updated Beers Criteria for potentially inappropriate medication use in older adults // J. Am. Geriatr. Soc. 2012. - Vol. 60 (4). - P. 616-631.

3. Explicit criteria for determining inappropriate medication use in nursing home residents. UCLA Division of Geriatric Medicine / M. H. Beers, J. G. Ouslander, I. Rollingher, D. Reuben, J. Brooks, J. C. Beck // Arch. Intern. Med. - 1991. - Vol. 151. - P. 1825-32.

4. Primejdie D. Potential inappropriate medication use in community - dwelling elderly patients. A qualitative study / D. Primejdie, M. Bojiță, A. Popa // FARMACIA. - 2012. Vol. 60. - P. 3.

5. Updating the Beers criteria for potentially inappropriate medication use in older adults: results of a US consensus panel of experts / D. M. Fick, J. W. Cooper, W. E. Wade, J. L. Waller, J. R. Maclean, M. H. Beers // Arch. Intern. Med. - 2003. - Vol. 163. - P. 2716-2724. (Published correction appears in Arch Intern Med. - 2004. Vol. 164. - P. 298t.)

6. Optimizing pharmacotherapy in elderly patients: the role of pharmacists / J. K. Lee, S. Alshehri, H. I. Kutbi, J. R. Martin // Integrated Pharmacy Research and Practice. 2015. - Vol. 4. - P. 101-111.

7. Nyborg G. Inappropriate prescribing for the elderly - a modern epidemic? / G. Nyborg, J. Straand, M. Brekke // Eur. J. Clin. Pharmacol. - 2012. - Vol. 68 (7). - P. 1085-1094.

8. Impact of pharmacist care in the management of cardiovascular disease risk factors: a systematic review and meta-analysis of randomized trials / V. Santschi, A. Chiolero, B. Burnand, A. L. Colosimo, G. Paradis // Arch. Intern. Med. - 2011. - Vol. 171 (16). - P. 1441-1453.

9. Walsh E. K. "Take ten minutes": a dedicated ten minute medication review reduces polypharmacy in the elderly / E. K. Walsh, K. Cussen // Ir. Med. J. - 2010. - Vol. 103 (8). - P. 236-238.

\section{REFERENCES}

1. Nobili A, Garattini S, Mannucci PM. Multiple diseases and polypharmacy in the elderly: challenges for the internist of the third millennium. Journal of Comorbidity. 2011;1:28-44

2. American Geriatrics Society 2012 Beers Criteria Update Expert Panel. American Geriatrics Society updated Beers Criteria for potentially inappropriate medication use in older adults. J Am Geriatr Soc. 2012;60(4):616-631

3. Beers MH, Ouslander JG, Rollingher I, Reuben D, Brooks J, Beck JC. Explicit criteria for determining inappropriate medication use in nursing home residents. UCLA Division of Geriatric Medicine. Arch Intern Med. 1991;151:1825-32

4. Primejdie D, Bojiță M, Popa A. Potential inappropriate medication use in community - dwelling elderly patients. A qualitative study. FARMACIA. 2012;60:3

5. Fick DM, Cooper JW, Wade WE, Waller JL, Maclean JR, Beers MH. Updating the Beers criteria for potentially inappropriate medication use in older adults: results of a US consensus panel of experts. Published correction appears in Arch Intern Med 2004;164:298t. Arch Intern Med. 2003;163:2716-24

6. Lee JK, Alshehri S, Kutbi HI, Martin JR. Optimizing pharmacotherapy in elderly patients: the role of pharmacists. Integrated Pharmacy Research and Practice. 2015;4:101-111

7. Nyborg G, Straand J, Brekke M. Inappropriate prescribing for the elderly - a modern epidemic? Eur J Clin Pharmacol. 2012;68(7):1085-1094.

8. Santschi V, Chiolero A, Burnand B, Colosimo AL, Paradis G. Impact of pharmacist 
care in the management of cardiovascular disease risk factors: a systematic review and meta-analysis of randomized trials. Arch Intern Med. 2011;171(16):1441-1453.
9. Walsh EK, Cussen K. "Take ten minutes": a dedicated ten minute medication review reduces polypharmacy in the elderly. Ir Med J 2010;103(8):236-8.

\section{УДК 615.21.3:34+616-039.42 \\ АНАЛИЗ ЛЕКАРСТВЕННЫХ НАЗНАЧЕНИЙ ПОЖИЛЫМ ЛЮДЯМ В УСЛОВИЯХ АПТЕКИ}

Т. Шкиопу, М. Брумэрел, Ст. Адаужи

В условиях роста количества пожилых людей все чаще различными международными организациями затрагивается проблема фармацевтической помощи этой категории людей. Фокус, ориентированный на потребность пожилых людей, определяется тем, что некоторые проблемы, связанные с применением ими лекарств, в настоящее время недостаточно изучены и не интерпретируются удовлетворительно. В Молдове сегодня нет статистических данных о состоянии здоровья лиц старше 65 лет и данных об их доступе к медицинским и фармацевтическим услугам. В этом контексте исследования в сфере гериатрической фармации Молдавии являются актуальными и практически значимыми. Материалом исследования послужили собранные в аптеках открытого типа в течение 5 месяцев подряд рецепты. Были проанализированы 1339 рецептов. Данными для анализа служили возраст, пол, даты назначения лекарства и его отпуска из аптеки, количество отпущенного лекарства одному пациенту, активное вещество и его доза. Исходя из анализируемых данных, были установлены современные проблемные вопросы, связанные с лекарственной терапией (режим дозирования, лекарственные взаимодействия, побочные эффекты), и предложены практические рекомендации для фармацевтов при предоставлении ими фармацевтических услуг пожилым людям, в том числе относительно объема и качества информации, предоставляемой во время отпуска лекарств. Ключевые слова: фармацевты; фармацевтические услуги; пожилые люди; лекарственная терапия; ожидаемые терапевтические результаты.

УДК 615.21.3:34+616-039.42

АНАЛІЗ ЛІКАРСЬКИХ ПРИЗНАЧЕНЬ ЛЮДЯМ ПОХИЛОГО ВІКУ В УМОВАХ АПТЕКИ

Т. Шкіопу, М. Брумерел, Ст. Адаужи

В умовах стрімкого зростання кількості літніх людей проблема фармацевтичної допомоги їм все частіше порушується різними міжнародними організаціями. Фокус, орієнтований на потреби літніх людей, визначається тим, що деякі проблеми, пов'язані з уживанням ліків, сьогодні недостатньо вивчені і не інтерпретуються задовільно. У Молдові на сьогодні відсутні статистичні дані про стан здоров'я осіб старше 65 років, а також дані про доступність для них медичних і фармацевтичних послуг. У цьому контексті дослідження у сфері геріатричної фармації Молдови є актуальними і мають практичне значення. Об'єктами дослідження стали зібрані в аптеках відкритого типу протягом 5 місяців поспіль рецепти. Проаналізовано 1339 рецептів. Аналізувалися вік, стать, дата призначення ліків, дата відпуску в рецепті, кількість лікарських засобів, відпущена одному пацієнту, активна речовина та режим дозування. Виходячи з результатів були встановлені сучасні проблеми, пов'язані з лікарською терапією (режим дозування, лікарські взаємодії, побічні ефекти), і запропоновані практичні рекомендації для фармацевтів при наданні фармацевтичних послуг людям похилого віку, зокрема і щодо обсягу та якості інформації, що надається під час відпуску ліків.

Ключові слова: фармацевти; фармацевтичні послуги; літні люди; лікарська терапія; очікувані терапевтичні результати. 